\title{
LCA of waste management systems-research opportunities
}

\author{
Shabbir H. Gheewala
}

Received: 14 July 2009 / Accepted: 22 July 2009 /Published online: 18 October 2009

(C) Springer-Verlag 2009

\section{Background}

Waste disposal is an important part of the life cycle of a product and is associated with environmental burdens like any other life-cycle stage. Management of waste at the end of life is broadly categorised into the following five systems:

- Waste minimisation

- Recycling

- Biological treatment

- Thermal treatment

- Landfill

The traditional "waste management hierarchy" has often been used in policy-making and is clearly applicable to waste prevention as the most favourable option, whereas landfill without energy recovery (waste of resources, both materials and energy) is the least favourable method. However, its utility for waste management systems in between the two extremes is debatable, while a holistic or "life-cycle" approach is appropriate for a proper comparative evaluation of various waste management systems (Barton et al. 1996; Finnveden et al. 2005; Chaya and Gheewala 2007; Del Borghi et al. 2009). Also, the waste management hierarchy cannot provide guidance vis-à-vis using a combination of waste treatment technologies in

Since 29 May 2009, Dr. Shabbir Gheewala is Subject Editor for the area "LCA of waste management systems".

S. H. Gheewala $(\bowtie)$

The Joint Graduate School of Energy and Environment,

King Mongkut's University of Technology Thonburi,

126 Pracha-Uthit Road, Bangmod, Tungkru,

Bangkok 10140, Thailand

e-mail: shabbir_g@jgsee.kmutt.ac.th integrated waste management systems; in such cases, too, an integrated assessment tool such as life cycle assessment (LCA) has been successfully used (McDougall and Hruska 2000; Liamsanguan and Gheewala 2008a), and studies abound on the application of this tool for decision support regarding waste management systems (Nyland et al. 2003; Wanichpongpan and Gheewala 2007; Liamsanguan and Gheewala 2008b).

\section{Research needs}

Despite the large number of applications of LCA to waste management policy and decision-making, there are several restrictions which need further research and refinement of the methodology. The assessment of waste management systems has deficiencies due to complications such as lack of proper inventory as well as multi-functionality (Doka and Hischier 2005). Emission measurements at waste management facilities (e.g. incinerators) are based on mixed waste input. Using average emission data for the varied input materials is not very meaningful; hence, waste models have been built to assess waste-specific burdens. Modelling long-term emissions from landfills both from the point-of-view of inventory as well as impact assessment is still under discussion. Limitations in the applicability of LCA as a decision-support tool in waste management planning and policy-making have been discussed in detail by Ekvall and colleagues (2007). The definition of the functional unit based on unit mass of waste input precludes the inclusion of waste-prevention activities as does the analysis of long-term trends in the assessment. Limitations in long-term decisions on waste management strategies, due to the following reasons, are some of the 
issues that need to be addressed (Ekvall et al. 2007; Winkler and Bilitewski 2007):

\section{- Static nature of traditional LCAs}

- Loss of site-specific, spatial information due to aggregation of each impact over the entire life cycle

- Lack of information on the fate of specific chemicals

- Linear steady-state modelling of probably non-linear systems

Multi-functionality of waste management systems leads to complexity in allocation with no clear-cut solution (Heijungs and Guinée 2007). The debate on the appropriate allocation methodology has been going on in LCA circles for many years, but a consensus is foreseeable. LCA has been traditionally used as a tool for environmental assessment; but from the sustainability perspective, economic and social impacts are also essential for decision-making. Efforts have been made to include financial costs as well as monetised environmental burdens through cost-benefit analysis and life-cycle costing (Carlson Reich 2005).

\section{Call for papers}

Most of the issues mentioned above are not limited to waste management but are also of concern to the general LCA methodology (Reap et al. 2008a, b). Nevertheless, their solution is a key area of interest for further research, which will hopefully lead to a more robust use of LCA in the assessment of waste management systems. The integration and complementarity of various environmental assessment and systems analysis tools is another topic of interest. As can be seen from the reference list, this area of research overlaps with journals dedicated to waste management as well as environmental science and engineering in general. However, the Int J Life Cycle Assess can provide a suitable forum for discussion on the methodological issues in the LCA community. Of course, case studies on the application of life-cycle thinking to waste management are always welcome as they will supply the working experience with life-cycle-based tools.

\section{References}

Barton JR, Dalley D, Patel VS (1996) Life cycle assessment for waste management. Waste Manag 16:35-50

Carlson Reich M (2005) Economic assessment of municipal solid waste management systems - case studies using a combination of life cycle assessment (LCA) and life cycle costing (LCC). J Clean Prod 13:253-263

Chaya W, Gheewala SH (2007) Life cycle assessment of MSW to energy schemes in Thailand. J Clean Prod 15:1463-1468

Del Borghi A, Gallo M, Del Borghi M (2009) A survey of life cycle approaches in waste management. Int $\mathrm{J}$ Life Cycle Assess. doi:10.1007/s11367-009-0111-7

Doka G, Hischier R (2005) Waste treatment and assessment of longterm emissions. Int J Life Cycle Assess 10(1):77-84

Ekvall T, Assefa G, Björklund A, Eriksson O, Finnveden G (2007) What life-cycle assessment does and does not do in assessments of waste management. Waste Manag 27:989-996

Finnveden G, Johansson J, Lind P, Moberg A (2005) Life cycle assessment of energy from solid waste-part 1: general methodology and results. J Clean Prod 13:213-229

Heijungs R, Guinée JB (2007) Allocation and 'what-if' scenarios in life cycle assessment of waste management systems. Waste Manag 27:997-1005

Liamsanguan C, Gheewala SH (2007) Environmental assessment of energy production from municipal solid waste incineration. Int $\mathrm{J}$ Life Cycle Assess 12(7):529-536

Liamsanguan C, Gheewala SH (2008a) The holistic impact of integrated solid waste management on greenhouse gas emissions in Phuket. J Clean Prod 16:1865-1871

Liamsanguan C, Gheewala SH (2008b) LCA: A decision support tool for environmental assessment of MSW management systems. J Environ Manag 87:132-138

McDougall FR, Hruska JP (2000) Report: the use of Life Cycle Inventory tools to support an integrated approach to solid waste management. Waste Manag Res 16:590-594

Nyland CA, Modahl IS, Raadal HL, Hanssen OJ (2003) Application of LCA as a Decision-Making Tool for Waste Management Systems. Int J Life Cycle Assess 8(6):331-336

Reap J, Roman F, Duncan S, Bras B (2008a) A survey of unresolved problems in life cycle assessment-part 1: goal and scope and inventory analysis. Int J Life Cycle Assess 13 (4):290-300

Reap J, Roman F, Duncan S, Bras B (2008b) A survey of unresolved problems in life cycle assessment - part 2: impact assessment and interpretation. Int J Life Cycle Assess 13(4):374-388

Wanichpongpan W, Gheewala SH (2007) LCA as a decision support tool for landfill gas-to-energy projects. J Clean Prod 15:1819-1826

Winkler J, Bilitewski B (2007) Comparative evaluation of life cycle assessment models for solid waste management. Waste Manag 27:1021-1031 